\title{
Differential Effects of Glucocorticoids and Mineralocorticoids on the mRNA Expression of Colon Ion Transporters in Infant Rats
}

\author{
ZHENG-MING WANG, MASATO YASUI, AND GIANNI CELSI \\ Department of Woman and Child Health, Karolinska Institute, Stockholm, Sweden
}

ABSTRACT

\begin{abstract}
Several epithelial ion transporters are developmentally regulated in the preweaning period, at the time when the circulating levels of glucocorticoid and mineralocorticoid hormones increase. The specific role of glucocorticoids and mineralocorticoids in the maturation of epithelial ion transport is still disputed. In this study, we investigated the effect of corticosteroids on the mRNA expression of ion transporters in the infant rat colon, a glucocorticoid- and mineralocorticoid-sensitive organ. The expression of the Na,K-ATPase, the H,K-ATPase and the amiloride-sensitive $\mathrm{Na}^{+}$channel mRNA was investigated in control rats from fetal to adult life. We found that the mRNA of the three transporters is temporarily up-regulated in the preweaning period. Rats were then injected with a single dose of betamethasone or aldosterone at $10 \mathrm{~d}$ of age. The main effect was the glucocorticoid stimulation of the $\mathrm{Na}, \mathrm{K}$-ATPase mRNA within $6 \mathrm{~h}$ (4fold). Glucocorticoids did not alter $\mathrm{H}, \mathrm{K}-\mathrm{ATPase}$ nor $\mathrm{Na}^{+}$channel mRNA within $6 \mathrm{~h}$. Aldosterone moderately (1.7-fold) stimulated $\mathrm{Na}^{+}$channel within $6 \mathrm{~h}$, but did not alter $\mathrm{Na}, \mathrm{K}$ ATPase nor $\mathrm{H}, \mathrm{K}$-ATPase mRNA. Twenty-four hours after injection, both glucocorticoids and mineralocorticoids had less pronounced and distinct effects. In tissue with lower aldosterone
\end{abstract}

It is well established that corticosteroid hormones have an important influence on normal growth and differentiation. Several studies have suggested that such effects are mediated by modulating the level or the activity of certain key enzymes involved in metabolic and physiologic processes $(1,2)$. The maturation of several ion transporters is developmentally regulated in the kidney and the intestine during the preweaning period, at the time when the circulating levels of both $\mathrm{GC}$ and MC hormones increase $(3,4)$. A deficiency of corticoids $(e . g$. adrenalectomy) delays tissue differentiation, and treatment with exogenous GC causes the premature appearance of normal events of development (5). The mechanisms by which corticosteroid hormones stimulate the maturation of epithelial ion transport is still disputed. GC may directly alter the tran-

Received October 27, 1994; accepted February 9, 1995.

Correspondence: Gianni Celsi, M.D., St. Göran's Children's Hospital, 1128I Stockholm, Sweden.

Supported by the Tore Nilsson Foundation and the Jeansson Foundation. receptor abundance (renal cortex) or with no aldosterone receptor (stomach), glucocorticoids induce a similarly rapid increases in $\mathrm{Na}, \mathrm{K}$-ATPase mRNA (4-fold within $6 \mathrm{~h}$ ), whereas aldosterone had no effect within 6 h. However, glucocorticoids did not stimulate $\mathrm{Na}, \mathrm{K}$-ATPase mRNA in the brain, a tissue rich in glucocorticoid receptors.

This study indicates that $\mathrm{Na}, \mathrm{K}$-ATPase is a primary target for glucocorticoids in the preweaning period, and suggests that glucocorticoid induction of $\mathrm{Na}, \mathrm{K}$-ATPase mRNA may play an important role in the maturation of epithelial ion transport capacity. The effect is probably mediated by glucocorticoids and not by mineralocorticoid receptors. However, it seems that an auxiliary factor is required for glucocorticoid-dependent stimulation of Na,K-ATPase mRNA. (Pediatr Res 38: 164-168, 1995)
Abbreviations
GC, glucocorticoid hormone
MC, mineralocorticoid hormone
11 $\beta$-HSD, 11 $\beta$-hydroxysteroid dehydrogenase
PCR, polymerase chain reaction

scription rate of key enzymes for cell metabolism, such as $\mathrm{Na}, \mathrm{K}$-ATPase (6). On the other hand, it has been suggested that GC may alter the phospholipid composition of the cell membrane (7). In the latter study, the alteration in phospholipids was accompanied by a change in the activity of membranebound ion transporters, such as the $\mathrm{Na}$-dependent phosphate, glucose, and proline carriers.

Several studies have shown that the activity of $\mathrm{Na}, \mathrm{K}$ ATPase is low in a variety of infant tissues, such as the kidney, lung, intestine, and heart, and that GC stimulate enzyme maturation (8-12). In the infant kidney, the transcription rate of $\mathrm{Na}, \mathrm{K}$-ATPase is directly increased by GC (6). GC do not regulate $\mathrm{Na}, \mathrm{K}$-ATPase mRNA in adults $(13,14)$. In adults, $\mathrm{Na}, \mathrm{K}$-ATPase mRNA is regulated by $\mathrm{MC}$, at least in aldosterone-sensitive cells (13). The role of aldosterone in the maturation of $\mathrm{Na}, \mathrm{K}$-ATPase is less well defined. Adrenal corticosteroids are known to have pronounced effects in the mammalian colon (15-18). The activity of colon $\mathrm{Na}, \mathrm{K}-\mathrm{ATPase}$ 
is low in infancy, and both aldosterone and GC have been shown to stimulate maturation of the enzyme activity $(4,19)$. The rat distal colon contains abundant $\mathrm{MC}$ and $\mathrm{GC}$ receptors which are expressed in epithelial surface and crypt cells (20, 21). Thus, the colon is an excellent model in which to study the specific role of GC and $\mathrm{MC}$ in the maturation of epithelial ion transporters. This study was therefore designed to determine the ontogeny of the basolateral Na,K-ATPase, the luminal $\mathrm{H}, \mathrm{K}$-ATPase (22), and the amiloride-sensitive $\mathrm{Na}^{+}$-channel (23) in the rat colon and to evaluate the role that GC and $\mathrm{MC}$ play in their maturation.

\section{MATERIAL AND METHODS}

Animals. Experiments were performed on male SpragueDawley rats aged $10 \mathrm{~d}$ (ALAB, Sollentuna, Sweden). The rats were injected intraperitoneally with betamethasone $(60 \mu \mathrm{g} / 100$ $\mathrm{g}$ body wt), aldosterone $(80 \mu \mathrm{g} / 100 \mathrm{~g}$ body wt), or vehicle. These doses were chosen because, in previous experiments, we found that they maximally accelerate the maturation of renal $\mathrm{Na}, \mathrm{K}$-ATPase $(8,24)$. The rats were then anesthetized after 6 or $24 \mathrm{~h}$ with thiobutabarbital $(8 \mathrm{mg} / 100 \mathrm{~g}$ body wt), and the organs were immediately removed. The distal colons (onethird part from the colorectal junction) were then cut open, emptied of all contents, and washed in ice-cold saline. In one protocol, control rats of various ages (20-d gestational age, 10 , 20 , and $50 \mathrm{~d}$ postnatally) were used. We pooled the organs from three to five fetuses before homogenization.

Northern and RNA dot blot hybridization. Total RNA was isolated from tissues, as previously described (3). The integrity of the RNA was routinely evaluated by Northern blot (Fig. 1). To quantify the mRNA level, $4 \mu \mathrm{g}$ of total RNA were denatured in ice-cold $10 \mathrm{mM} \mathrm{NaOH}$ and blotted in triplicate under vacuum onto a nylon filter, as previously described (10). Probes were random-prime labeled with ${ }^{32} \mathrm{P}$ (Megaprime DNA Labeling system, Amersham, Buckinghamshire, UK). Prehybridization $(20 \mathrm{~min})$ and hybridization $(3 \mathrm{~h})$ were performed at $65^{\circ} \mathrm{C}$ with Amersham Rapid Hybridization buffer. Filters were washed at $65^{\circ} \mathrm{C}$ to a final stringency of $0.1 \times \mathrm{SSPE}, 0.1 \%$ SDS. The filters were subjected to autoradiography at $-70^{\circ} \mathrm{C}$ and the results analyzed by laser densitometry. Data were corrected by

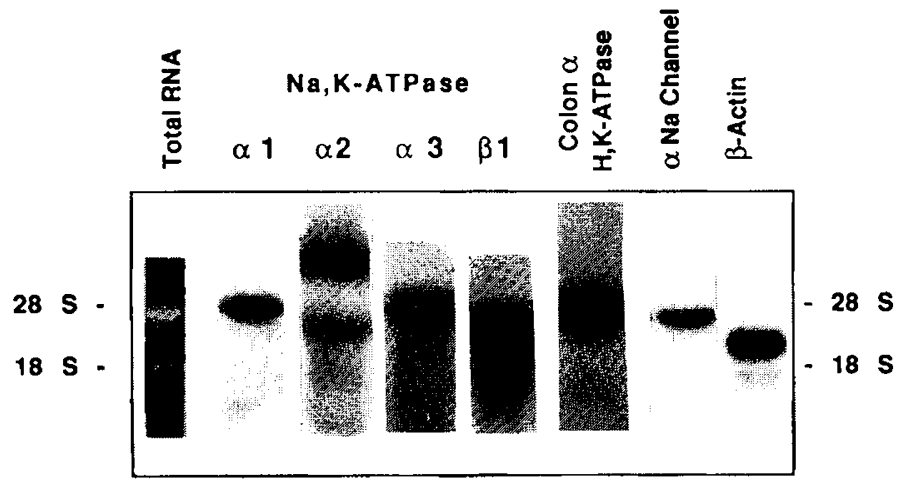

Figure 1. Representative Northern blot analysis. Ten micrograms of total RNA were loaded in each lane and probed with $\alpha 1, \alpha 2, \alpha 3$, and $\beta 1 \mathrm{Na}, \mathrm{K}$ ATPase, colon $\alpha \mathrm{H}, \mathrm{K}$-ATPase, $\alpha \mathrm{Na}$-channel, and $\beta$-actin cDNAs, respectively. Positions of ribosomal $18 \mathrm{~S}$ and $28 \mathrm{~S}$ are indicated. Ethidium bromide staining of total RNA is also illustrated. the intensity of an internal standard (pooled mRNA from control rats) to which an arbitrary value of 1 is given. Expression of actin mRNA was also routinely determined to evaluate appropriate loading. The $\mathrm{Na}, \mathrm{K}$-ATPase $\alpha 1$ and $\alpha 2$ probes are full-length cDNAs, $\alpha 3$ is the Pst $\mathrm{I}-S m a \mathrm{I}$ fragment $(278 \mathrm{bp})$ and $\beta 1$ is the HindIII- PstI fragment (271 bp). Actin cDNA was purchased from Clontech Labs, Palo Alto, CA. The colon H,K-ATPase $\alpha$ subunit and the Na-channel $\alpha$ subunit probes are 421- and 223-bp fragments (53-473 and 86-308 nucleotides, respectively) which were synthetized from rat colon and renal mRNA by reverse transcriptase-PCR. PCR primers $(20$ mer) were designed according to the published sequence (23, 25). RNA ( $2 \mu \mathrm{g}$ ) was reverse transcribed in a $20-\mu \mathrm{L}$ reaction containing $50 \mathrm{mM}$ Tris- $\mathrm{HCl}, 75 \mathrm{mM} \mathrm{KCl}, 3 \mathrm{mM} \mathrm{MgCl}, 1 \mathrm{mM}$ DTT, $2 \mathrm{mM} \mathrm{dNTP}, 25 \mathrm{mg} / \mathrm{mL}$ oligo(dT), $30 \mathrm{U}$ RNasin, and $100 \mathrm{U}$ Moloney murine leukemia virus reverse-transcriptase. After incubation for $30 \mathrm{~min}$ at $42^{\circ} \mathrm{C}$, the samples were used for PCR amplification. Reactions were performed in $10 \mathrm{mM}$ Tris$\mathrm{HCl}, 50 \mathrm{mM} \mathrm{KCl}, 1.5 \mathrm{mM} \mathrm{MgCl}_{2}, 50 \mathrm{pM}$ of each primer and 2 U Taq DNA polymerase. The following temperature profile was used: $1 \mathrm{~min}$ at $94^{\circ} \mathrm{C}, 1 \mathrm{~min}$ at $55^{\circ} \mathrm{C}$, and $2 \mathrm{~min}$ at $72^{\circ} \mathrm{C}(35$ cycles). Gel analysis of the PCR products showed unique bands of the predicted size.

Statistical analysis. Six rats were studied in each group. Values are given as means $\pm \mathrm{SD}$. The statistical analysis was performed with the $t$ and analysis of variance test.

\section{RESULTS}

In the colon, the expression of the $\mathrm{Na}, \mathrm{K}$-ATPase $\alpha 1$ and $\beta 1$ subunits, the H,K-ATPase $\alpha$ subunit, and Na-channel $\alpha$ subunit was ontogenically regulated. For clarity of presentation, only the $\mathrm{Na}, \mathrm{K}$-ATPase $\beta 1$ subunit mRNA is shown throughout this report, because $\alpha 1$ and $\beta 1$ mRNA always changed in parallel. The mRNA of all three ion transporters are expressed in the fetal colon (Fig. 2). Postnatally, the mRNA of all three ion transporters increased to a maximal level in the preweaning period $(\approx 20 \mathrm{~d}$ of age) and then declined to the adult level $(p$ $<0.05$ for all mRNA, analysis of variance test).

It is well established that the circulating levels of GC and $\mathrm{MC}$ increase during the $3 \mathrm{rd}$ wh of life $(3,4)$. To evaluate whether the temporary up-regulation of the Na,K-ATpase, $\mathrm{H}, \mathrm{K}$-ATPase, and Na-channel mRNA is due to corticoids, rats

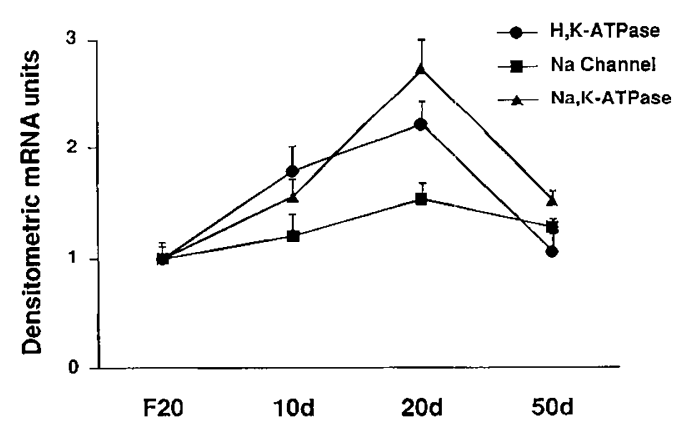

Figure 2. Ontogenic changes of colon $\beta 1 \mathrm{Na}, \mathrm{K}$-ATPase, $\alpha \mathrm{H}, \mathrm{K}$-ATPase, and $\alpha$ Na-channel mRNA in normal rats from fetal life (20-d gestational age, F20) to adult life $(10,20$, and $50 \mathrm{~d}$ postnatally). An arbitrary value of 1 has been assigned to mRNA abundance in F20 rats. 
were given a single injection of betamethasone or aldosterone at $10 \mathrm{~d}$ of life-i.e. before the physiologic surge of corticosteroids occurs. GC had different effects on the mRNA of the three ion transportrers in the colon (Fig. 3). The Na,K-ATPase mRNA increased rapidly after GC injection. The effect was greater after $6 \mathrm{~h}$ ( $\approx 4$-fold increase over sham-injected animals) than after $24 \mathrm{~h}$. GC also stimulated the H,K-ATPase mRNA. However, the effect was moderate and occurred only after $24 \mathrm{~h}$ (1.6-fold). GC did not alter the Na-channel mRNA at 6 or at 24 h. The injection of aldosterone caused less distinct effects (Fig. 3). Na,K-ATPase mRNA was not altered $6 \mathrm{~h}$ after the treatment. Twenty-four hours after injection, the expression of Na,K-ATPase mRNA was moderately but significantly increased in aldosterone-treated rats (1.9-fold). The H,K-ATPase mRNA showed a similar pattern; the mRNA was not alterd after $6 \mathrm{~h}$ but moderately increased after $24 \mathrm{~h}$ (1.8-fold). The $\mathrm{Na}$-channel mRNA was moderately but significantly increased after both 6 and $24 \mathrm{~h}$ ( $\approx 1.7$-fold).

To further exclude that GC might activate Na,K-ATPase by cross-binding to $\mathrm{MC}$ receptors, we studied the effects of corticosteroid treatment in tissue with a low level of $\mathrm{MC}$ receptor
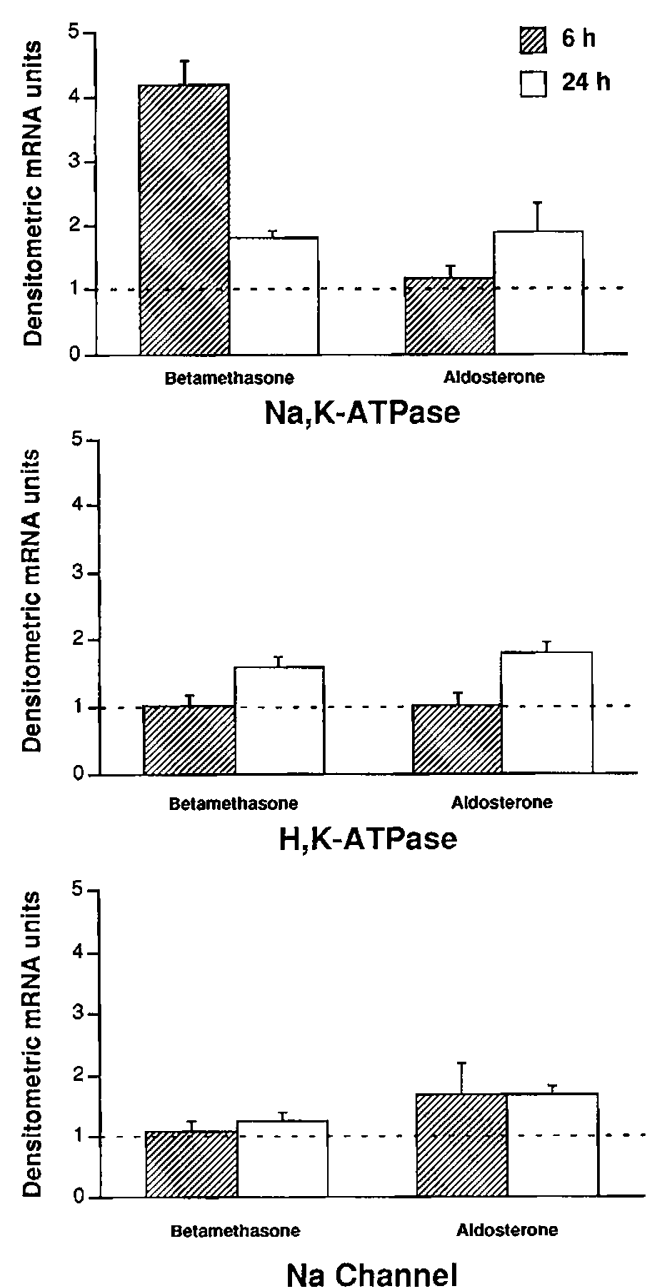

Figure 3. Effects of corticosteroid treatment on $\beta 1 \mathrm{Na}, \mathrm{K}$-ATPase, $\alpha \mathrm{H}, \mathrm{K}$ ATPase, and $\alpha$ Na-channel mRNA in colon from 10-d-old rats. Rats were given injections of betamethasone 6 or $24 \mathrm{~h}$ before the experiment. An arbitrary value of 1 has been assigned to mRNA abundance in control rats (dotted line). (renal cortex) and in aldosterone-independent tissue (stomach). After $6 \mathrm{~h}, \mathrm{GC}$ but not aldosterone injection resulted in a significant increase in renal and gastric $\mathrm{Na}, \mathrm{K}-\mathrm{ATP}$ ase mRNA ( $\approx 4$-fold in both tissues) (Fig. 4). The effects of GC was greater after $6 \mathrm{~h}$ than after $24 \mathrm{~h}$. The effects of $\mathrm{GC}$ were also studied in brain, a tissue rich in $\mathrm{GC}$ receptors and $\mathrm{Na}, \mathrm{K}$ ATPase (Fig. 5). Six hours after injection, GC had no effect on brain $\alpha 1, \alpha 2, \alpha 3$, and $\beta 1 \mathrm{Na}, \mathrm{K}$-ATPase mRNA.

\section{DISCUSSION}

This study suggests that the GC stimulation of Na,K-ATPase mRNA may play a central role in the postnatal maturation of colon function. The function of the intestine matures most rapidly during the transition from ingestion of milk to solid food $(26,27)$, and corticosteroids play an important role in this process $(1,2)$. The activity of several enzymes involved in transepithelial ion transport undergoes a postnatal maturation regulated by circulating GC (5). Both direct and indirect mechanisms have been suggested to explain the effect of steroids on epithelial ion transporter maturation. It has been shown that GC induce a change in the phospholipid composition of the cell membrane and, therefore, may indirectly influence the transport of phosphate, glucose, and amino acids (7). Changes in the composition of phospholipids alter the membrane fluidity and therefore the activity of membrane-bound enzymes (28).

On the other hand, GC may directly affect enzymes that play a key role in transepithelial ion transport. In this study, we investigated the maturation of the basolateral $\mathrm{Na}, \mathrm{K}$-ATPase,
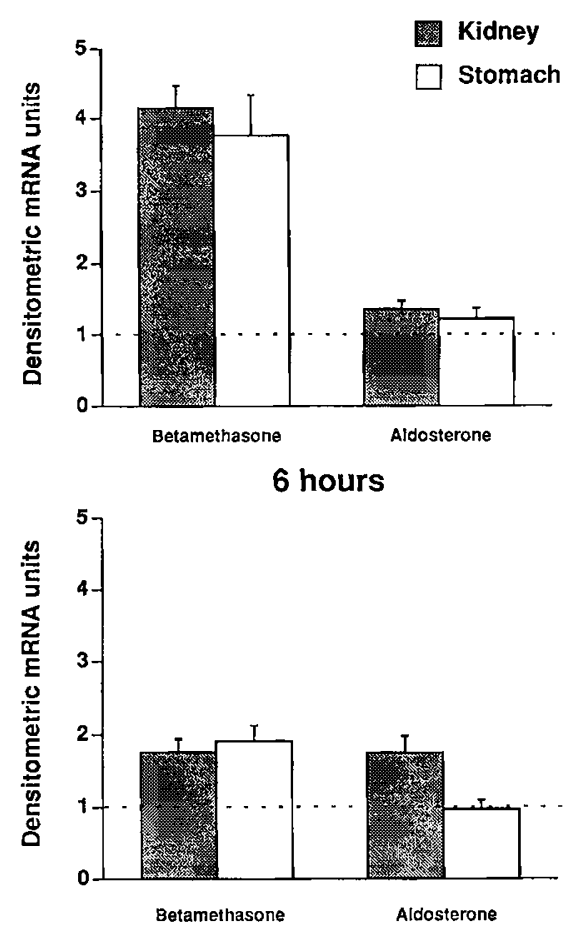

24 hours

Figure 4. Effects of betamethasone and aldosterone on $\beta 1 \mathrm{Na}, \mathrm{K}$-ATPase mRNA in kidney and stomach from 10 -d-old rats. Rats were given injections of betamethasone or aldosterone 6 and $24 \mathrm{~h}$ before the experiment. An arbitrary value of 1 has been assigned to mRNA abundance in control rats (dotted line). 


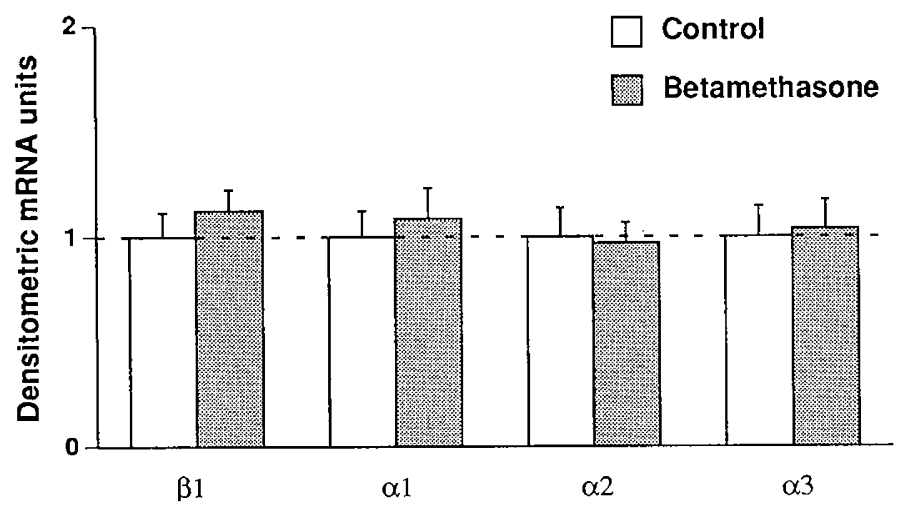

Figure 5. Effect of betamethasone treatment on $\alpha 1, \alpha 2, \alpha 3$, and $\beta 1 \mathrm{Na}, \mathrm{K}$ ATPase mRNA in brain from 10 -d-old rats. Rats were given injections of betamethasone $6 \mathrm{~h}$ before the experiment. An arbitrary value of 1 has been assigned to mRNA abundance in control rats.

the luminal H,K-ATPase, and the amiloride-sensitive Nachannel. We found that the mRNA of these ion transporter are temporarily up-regulated in the preweaning period. A similar up-regulation of $\mathrm{Na}, \mathrm{K}$-ATPase mRNA has been found in other tissues, corresponding to the period of their most rapid maturation (29). These results suggest that an increased synthesis of ion transporters occurs during weaning. In the rat, the circulating level of $\mathrm{GC}$ and $\mathrm{MC}$ increases in the preweaning period $(3,4)$, and it has been shown that the maturation of colon $\mathrm{Na}, \mathrm{K}-\mathrm{ATPase}$ activity can be accelerated by GC and MC (4, 11). To determine whether the up-regulation of the colon transporter mRNA is due to corticosteroids, betamethasone, and aldosterone were injected into 10 -d-old rats-i.e. before the upsurge in circulating corticosteroids occurs. Inasmuch as the levels of endogenous hormones are very low during the first 2 postnatal wk, a maximal response to injected hormones can be expected in these infant rats. Nevertheless, only the $\mathrm{Na}, \mathrm{K}$ ATPase mRNA was rapidly and markedly stimulated by GC in the infant colon (4-fold over controls). GC induced no change in Na-channel mRNA and only moderate and late changes in H,K-ATPase mRNA. Aldosterone had only moderate and late effects on Na,K-ATPase and H,K-ATPase mRNA. The effect of aldosterone on Na-channel mRNA was also moderate. The finding that the strong GC effect on Na,K-ATPase occurs at an earlier stage than the moderate effect on other ion transporters may indicate that $\mathrm{Na}, \mathrm{K}$-ATPase is a primary target for $\mathrm{GC}$ in the preweaning period.

$\mathrm{Na}, \mathrm{K}$-ATPase is an integral membrane protein that is present in all mammalian cells. By actively pumping $3 \mathrm{Na}^{+}$out of the cell and $2 \mathrm{~K}^{+}$into the cell, the $\mathrm{Na}, \mathrm{K}$-ATPase generates a $\mathrm{Na}^{+}$ gradient that is used by the cell to run a variety of "secondary" $\mathrm{Na}^{+}$-dependent transporters (30). Glucose, amino acids, and other essential ions, such as hydrogen and phosphates, are moved across the cell membrane by these carriers. Na,KATPase enzyme is therefore the key enzyme for normal cell homeostasis and for fluid movement across epithelial layers. Becaue the enzyme provides the driving force for a variety of ion transporters, it is highly likely that the limited availability of Na,K-ATPase activity is a rate-limiting step for cellular function in immature cells. The activity of $\mathrm{Na}, \mathrm{K}$-ATPase is low in most infant tissues. It has been suggested that hyperkalemia in preterm babies may be due, in part, to a shift of potassium from the intracellular space to the extracellular space with low Na,K-ATPase activity (31). The maturation of the concentrating capacity closely follows the maturation of renal $\mathrm{Na}, \mathrm{K}$ ATPase (5). The present study therefore suggests that GC induction of $\mathrm{Na}, \mathrm{K}$-ATPase mRNA may play an important role in the maturation of tissue function.

The mechanisms whereby corticosteroids regulate $\mathrm{Na}, \mathrm{K}$ ATPase mRNA are still debated. We have recently found that the transcription rate of $\mathrm{Na}, \mathrm{K}$-ATPase gene is increased by $\mathrm{GC}$ in the infant kidney and that infant $\mathrm{GC}$ receptors bind to the $\mathrm{Na}, \mathrm{K}$-ATPase promoter (6). The effect of GC is tissue-specific and occurs only in tissues that are rapidly maturing (9). GC do not seem to be necessary for $\mathrm{Na}, \mathrm{K}$-ATPase transcription in the adult renal cortex, because adrenalectomy does not affect the abundance of $\mathrm{Na}, \mathrm{K}$-ATPase mRNA in proximal tubules (13, 14), nor does GC treatment in control rats alter renal $\mathrm{Na}, \mathrm{K}$ ATPase mRNA (3). In the adult colon, it has been reported that GC but not aldosterone increase Na,K-ATPase mRNA. However, the effect of GC was almost completely abolished by cycloheximide, suggesting an indirect effect (32). Some data indicate that aldosterone may regulate $\mathrm{Na}, \mathrm{K}$-ATPase mRNA in the adult rat colon through a thyroxine-dependent pathway (33). In situ hybridization studies show that in adrenalectomized adult rats the $\mathrm{Na}, \mathrm{K}$-ATPase mRNA abundance is reduced in MC-sensitive segments of the nephron--i.e. the distal tubule and the collecting duct (13). The effect of aldosterone on the biosynthesis of Na,K-ATPase has been studied in cultured amphibian A6 renal cells. In these cells, there is evidence of a direct aldosterone-dependent enhancement of the $\mathrm{Na}, \mathrm{K}$ ATPase transcription rate (34). However, it has recently been shown that the aldosterone stimulation of $\mathrm{Na}^{+}$transport in $\mathrm{A} 6$ cells is mediated by $\mathrm{GC}$ receptors and not by $\mathrm{MC}$ receptors (35). The present study clearly indicates that GC have a more direct effect on infant colon Na,K-ATPase mRNA than aldosterone does, suggesting that, in infant colon cells, aldosterone does not directly regulate $\mathrm{Na}, \mathrm{K}$-ATPase gene transcription. The GC and MC receptors are very abundant and homogeneously expressed in colon surface and crypt cells $(20,36)$, and therefore compartimentalization of the receptors should not account for this differential response. In the present paper, aldosterone seems to activate the Na-channel mRNA. Amiloride-sensitive $\mathrm{Na}^{+}$channels mediate the first step of active $\mathrm{Na}^{+}$reabsorption in numerous epithelia, such as the distal nephron and the distal colon (37). Aldosterone is the major regulator of $\mathrm{Na}^{+}$reabsorption, acting via an increase in the apical $\mathrm{Na}^{+}$permeability (38). It has been suggested that the cytoplasmic $\mathrm{Na}^{+}$concentration serves as a mediator for the action of aldosterone because a correlation between intracellular $\mathrm{Na}^{+}$and the amount of $\mathrm{Na}, \mathrm{K}$-ATPase has been established (39). It therefore seems possible that aldosterone may contribute to maturation of the colon by increasing $\mathrm{Na}^{+}$entry and secondarily stimulating Na,K-ATPase mRNA.

Steroid hormones bind to cytoplasmic receptors which, after ligand binding, are transported into the nucleus where they regulate the transcription of target genes by binding to specific DNA sequences (40). It is a paradox that GC and aldosterone have very similar receptors, bind to both receptors with a very 
similar affinity, recognize the same DNA binding element, and yet have different physiologic functions. The presence of $11 \beta-$ HSD in aldosterone-sensitive tissues has been thought to mediate the specificity (19). The enzyme protects these tissues from the circulating levels of $\mathrm{GC}$, because it rapidly metabolizes cortisol and corticosterone to inactive metabolites. Therefore only aldosterone can bind to its receptor and activate gene transcription. Besides the ubiquitously distribution of the receptors for MC and GC, the $11 \beta$-HSD is also expressed in the colon (20). The results of the present study seem to indicate that mechanisms besides $11 \beta$-HSD mediate the specificity of corticosteroid action. Similar doses of GC and MC were used, yet the specificity was preserved. The finding that, in tissue with low MC receptors (kidney) (41) or aldosteroneindependent tissue (stomach) (42), the Na,K-ATPase mRNA increased rapidly after $\mathrm{GC}$ in a sinilar manner seems to indicate that the $\mathrm{GC}$ receptor and not the $\mathrm{MC}$ receptor mediates the response. However, the observation that, in a tissue such as the brain where both $\mathrm{Na}, \mathrm{K}$-ATPase and $\mathrm{GC}$ receptors are abundant and ubiquitous (43, 44), GC did not stimulate an increase in $\mathrm{Na}, \mathrm{K}$-ATPase mRNA seems to indicate that other factors are necessary in addition to the $\mathrm{GC}$ receptor. It has been recently demonstrated that the specificity of $\mathrm{GC}$ and $\mathrm{MC}$ hormones can be mediated by the interaction of the receptors with other nuclear proteins (45). The promoter of $\mathrm{Na}, \mathrm{K}$ ATPase appears to interact with both the GC (6) and the MC receptors (46). The Na,K-ATPase gene could therefore be an useful model for studying the molecular mechanisms preserving the specificity of GC and MC action.

Acknowledgment. We thank Prof A. Aperia for fruitful discussions.

\section{REFERENCES}

1. Greengard O 1973 Effects of hormones on development of fetal enzymes. Clin Pharmacol Ther 14:721-726

2. Henning SJ, Sims JM 1979 Delineation of the glucocorticoid-scnsitive period of intestinal devclopment in the rat. Endocrinology 104:1158-1163

3. Celsi G, Nishi A, Akusjärvi G and Aperia A 1991 Abundance of $\mathrm{Na}^{+}-\mathrm{K}^{+}$-ATPasc mRNA is regulated by glucocorticoid hormones in infant rat kidneys. Am J Physiol 260:F192-F197

4. Finkel Y, Aperia A 1986 Rolc of aldosterone for control of colonic Na,K-ATPase activity in weanling rats. Pediatr Res 20:242-245

5. Aperia A, Celsi G 1992 Ontogenic processes in nephron epithelia: Structure, enzymes, and function. In: Seldin W and Giebisch G (eds) The Kidney: Physiology and Pathophysiology. Raven Press, New York, pp 803-828

6. Wang Z-M, Yasui M, Celsi G 1994 Glucocorticoids regulatc the transcription of Na,K-ATPase genes in the infant rat kidney. Am J Physiol 267:C450-C455

7. Arar M, Levi M, Baum M 1994 Maturational effects of glucocorticoids on neonatal brush-border membrane phosphate transport. Pediatr Res 35:474-478

8. Igarashi Y, Apcria A, Larsson L, Zctterström R 1983 Effect of betamcthasone on Na-K-ATPase activity and basal and latcral cell membranes in proximal tubular celis during early devclopment. Am J Physiol 245:F232-F237

9. Celsi G, Wang Z-M, Akusjärvi G, Aperia A 1993 Sensitive periods for glucocorticoids' regulation of $\mathrm{Na}^{+}, \mathrm{K}^{+}$-ATPase $\mathrm{mRNA}$ in developing lung and kidncy. Pediatr Res 33:5-9

10. Wang Z-M, Celsi G 1993 Glucocorticoid hormoncs differentially regulatc the mRNA for $\mathrm{Na}^{+}, \mathrm{K}^{+}$-ATPase isoforms in infant heart. Pediatr Res 33:1-4

11. Verma RP, Horvath K, Blochin B, Lu R-B, Wang W, Lebenthal E 1994 Maturational response of colonic and renal $\mathrm{Na}^{+}, \mathrm{K}^{1}-\mathrm{ATPase}$ activity and $\mathrm{K}^{+}$load and betamethasonc in preterm rats. J Lab Clin Med 123:676-684

12. Zemelman BV, Walker WA, Chu S 1992 Expression and developmental regulation of $\mathrm{Na}^{+}, \mathrm{K}^{+}$-adcnosine triphosphatase in the rat small intestine. J Clin Invest 90:10161022

13. Farman N, Coutry N, Logvinenko N, Blot-Chabaud M, Bourbouze R, Bonvalet JP 1992 Adrenalectomy reduces $\alpha 1$ and $\beta 1 \mathrm{Na}^{-1}-\mathrm{K}^{+}$-ATPase mRNA expression in rat distal nephron. Am J Physiol 263:C810-C817

14. Celsi G, Stålh J, Wang Z-M, Nishi A 1992 Adreno-corticoid regulation of $\mathrm{Na}^{+}, \mathrm{K}^{\text {}}$ ATPase in adult rat kidney: effects on posttranslational processing and mRNA abundance. Acta Physiol Scand 145:85-91
15. Bastl C, Schulman G, Cragoe EJJ 1989 Low-dose glucocorticoids stimulatc clectroneutral $\mathrm{NaCl}$ absorption in rat colon. Am J Physiol 257:F1027-F1038

16. Binder HJ, McGlone F, Sandle GI 1989 Effects of corticosteroid hormones on the elcctrophysiology of rat distal colon: Implications for $\mathrm{Na}$ and $\mathrm{K}$ transport. J Physiol 410:425-441

17. Foster ES, Zimmerman TW, Hayslett JP, Binder HJ 1983 Corticosteroid altcration of active electrolyte transport in rat distal colon. Am J Physiol 245:G668-G675

18. Sandle GI, Binder HJ 1987 Corticosteroids and intestinal ion transport. Gastroenterology 93:188-196

19. Funder J, Pearce P, Smith R, Smith A 1988 Mineralocorticoid action: Target tissue specificity is enzyme, not receptor, mediated. Science 242:583-585

20. Whorwood CB, Baarber PC, Gregory J, Sheppard MC, Stcwart PM 1993 11- $\beta$ Hydroxysteroid dehydrogenase and corticosteroid hormone receptors in the rat colon. Am J Physiol 264:E951-E957

21. Fuller PJ, Verity K 1990 Minerocorticoid receptor genc expression in the gastrointestinal tract: Distribution and ontogeny. J Steroid Biochem 36:263-267

22. Jaisser F, Coutry N, Farman N, Binder HJ, Rossier BC 1993 A putative $\mathrm{H}^{+-}-\mathrm{K}^{+}$ ATPase is selectively expressed in surface cpithelial cclls of rat distal colon. Am J Physiol 265:C1080-C1089

23. Canessa C, Horisberger J-D, Rossier B 1993 Epithclial sodium channel related to proteins involved in neurodegencration. Nature 361:467-470)

24. Aperia A, Larsson L, Zetterström R 1981 Hormonal induction of Na-K-ATPase in developing proximal tubular cells. Am J Physiol 241:F356-F360

25. Crowson M, Shull G 1992 Isolation and characterization of a cDNA encoding the putative distal colon $\mathrm{H}^{+}, \mathrm{K}^{++}$-ATPase. J Biol Chem 267:13740-13748

26. Kretchmer N 1985 Weaning: Enzymatic adaptation. Am J Clin Nutr 41:391-398

27. Henning S 1981 Postnatal development: Coordination of fecding, digestion, and metabolism. Am J Physiol 241:G199-G214

28. Kimelberg H 1977 The influence of membrane fluidity on the activity of membranebound enzymes. In: Postc G (ed) Dynamics Aspects of Cell Surface organization. Elsevicr, Berlin, pp 205-293

29. Orlowski J, Lingrel JB 1988 Tissue-specific and developmental regulation of rat $\mathrm{Na}, \mathrm{K}-\mathrm{ATP}$ ase catalytic $\alpha$ isoform and $\beta$ subunit mRNAs. J Biol Chem 263:1043610442

30. Jörgensen PL 1986 Structure, function and regulation of Na,K-ATPase in the kidney. Kidney Int 29:10-20

31. Stefano J, Norman M, Morales M, Goplcrud J, Mishra O, Delivoria-Papadopoulos M 1993 Decreased erythrocyte Na,K-ATPase activity associated with ccllular potassium loss in extremely low birth weight infants with nonoliguric hyperkalcmia. J Pediatr 122:276-284

32. Fuller PJ, Verity K 1990 Colonic sodium-potassium adenosine triphosphate subunit gene expression: Ontogeny and regulation by adrenocortical steroids. Endocrinology 127:32-38

33. Wiener H, Niclsen JM, Klacrke DA, Jörgensen P 1993 Aldostcrone and thyroid hormonc modulation of $\alpha 1, \beta 1$-mRNA, and Na,K-pump sites in rabbit distal colon epithelium. Evidence for a novel mechanism of cscape from the effect of hyperaldostcronemia. J Membr Biol 133:203-211

34. Verrey F, Kraehenbuhl JP, Rossier BC 1989 Aldosterone induces a rapid increase in the ratc of Na,K-ATPase genc transcription in cultured kidncy cells. Mol Endocrinol 3:1369-1376

35. Schmidt TJ, Husted R, Stokes J 1993 Steroid hormone stimulation of Na transport in A6 cells is mediated via glucocorticoid receptors. Am J Physiol 264:C875-C884

36. Schulman G, Roberston N, Elfcbein I, Encanya D, Litwack G, Bastl C 1994 Mineralocorticoid and glucocorticoid receptor steroids binding and localization in colonic cclls. Am J Physiol 266:C729-C740

37. Bcnos D, Sorscher E 1992 Transport protcins: Ion channels. In: Seldin DW and Giebisch G (eds) The Kidncy: Physiology and Pathophysiology. Raven Press, New York, pp 595-597

38. Rossier BC, Palmer LG 1992 Mcchanisms of aldosterone action on sodium and potassium transport. In: Seldin DW and Giebisch G (eds) The Kidney: Physiology and Pathophysiology. Raven Press, New York, pp 1373-1409

39. Ikeda U, Hyman R, Smith TW, Medford RM 1991 Aldosterone-mediated regulation of $\mathrm{Na}^{+}, \mathrm{K}^{\prime}$-ATPase gene expression in adult and nconatal rat cardiocytes. J Biol Chem 266:12058

40. Yamamoto KR 1985 Steroid receptor regulated transcription of specific genes and gene networks. Arnu Rev Genet 19:209-252

41. Todd-Turla KM, Schnermann J, Fejes-Tóth G, Naray-Fejcs-Tóth A, Smart A, Killen PD, Brigs JP 1993 Distribution of mineralocorticoid and glucocorticoid receptor mRNA along the ncphron. Am J Physiol 264:F781-F791

42. Fuller P, Verity K 1990 Mineralocorticoid receptor gene expression in the gastrointestinal tract: Distribution and ontogeny. J Steroid Biochem 36:263-267

43. Watts A, Sanchez-Watts G, Emanuel J, Levenson R 1991 Ccll-specific cxpression of mRNAs encoding $\mathrm{Na}, \mathrm{K}$-ATPase $\alpha$ - and $\beta$-subunit isoforms within the rat central nervous system. Proc Natl Acad Sci USA 88:7425-7429

44. Gustafsson J-Å, Carlstedt-Duke J, Poellinger L, Okret S, Wikström A-C, Brönnegård M, Gillner M, Dong Y, Fuxe K, Cintra A, Härfstrand A, Agnati L 1987 Biochemistry, molecular biology, and physiology of the glucocorticoid receptor. Endocr Rev $8: 185-234$

45. Pearce D, Yamamoto K 1993 Mineralocorticoid and glucocorticoid reccptor activities distinguished by nonrcceptor factors at a compositc response element. Science 259:1161-1165

46. Oguchi A, Ikeda U, Kanbe T, Tsuruya Y, Yamamoto K, Kawakami K, Medford R, Shimuda K 1993 Regulation of Na-K-ATPase gene expression by aldosterone in vascular smooth muscle cells. Am J Physiol 265:H1167-H1172 